Acta vet. scand. $1984,25,113-127$.

From the Department of Animal Hygiene, College of Veterinary Medicine, Swedish University of Agricultural Sciences, Uppsala and the Laboratory for Comparative Pathology, National Veterinary Institute, Stockholm, Sweden.

\title{
THE INFLUENCE OF AGE, BREED, REARING INTENSITY AND EXERCISE ON THE INCIDENCE OF SPAVIN IN SWEDISH DAIRY CATTLE
}

A CLINICAL AND MORPHOLOGICAL INVESTIGATION

\author{
By \\ Torbjörn Holmberg and Sven Reiland
}

HOLMBERG, TORBJöRN and SVEN REILAND: The influence of age, breed, rearing intensity and exercise on the incidence of spavin in Swedish dairy cattle. Acta vet. scand. 1984, 25, 113-127. - The hocks of tied cows of a Swedish dairy herd of different breeds were radiographed. Osteoarthrosis of the arthrodial joints (spavin) was found in $37 \%$ of the animals. Changes were seen before the cows were 2 years old, and they increased in severity with increasing age. Macroscopic and histologic examination revealed that there was osteoarthrosis also in many radiologically normal hocks. The study shows that the frequency of spavin in tied dairy cows is higher than clinical signs indicate. Apparently only cows with fusion of the arthrodial joints show the stiff hind leg movements considered typical of spavin. Differences in the incidence of spavin were found between the different breeds. Cows of the Swedish Friesian breed had the lowest $(20 \%)$ and cows of the Jersey breed had the highest $(50 \%)$ incidence of spavin. However, as regards the Jersey breed this was due to the high incidence $(71 \%)$ found in cows raised on a high intensity feeding during the young stock period. Among the SJB cows raised on a normal intensity feeding the incidence of spavin was $25 \%$. Such a relationship between high young stock feeding intensity and the incidence of spavin was not seen within the other breeds. The cows in another herd with loose housing had a lower frequency of spavin than the tied cows. Offspring of animals with spavin had a higher incidence of spavin than the offspring of animals without spavin.

spavin; dairycattle; breed; feeding intensity; e $\mathrm{x}$ e r c is e. 
Next to low fertility, diseases of the udder and unsatisfactory milk yield, foot and leg problems are the most common cause of culling in dairy herds (SHS 1976 and 1978). The underlying morphologic changes are, however, not well known.

The hind legs of tied cows are said to be more exposed to stress and strain than the fore legs and therefore more prone to develop foot and leg problems (Shupe 1959, Greenough et al. 1972, Assmus 1975, Weaver 1977, Russell \& Shaw 1978).

In an investigation in progress (Berglund et al. 1980), the development of the skeleton and the joints in tied dairy cows in a herd of different breeds and on different feeding intensities is presently being studied. It was discovered that a large percentage of the tied cows suffered from spavin. This lesion was first described by Blumenfeld (1909). Since then, spavin in cattle has been classified in different ways by different authors, e.g. as osteoarthropathy (Groulade et al. 1960), arthritis serosa tarsi (Hansen 1964), chronic deformative arthritis (Assmus 1975) or aseptic tarsitis (Greenough et al. 1972).

The aim of the present investigation was primarily to determine the influence of genetic and environmental factors on the incidence of spavin in animals of the above mentioned herd. The second aim was to find out if a correlation exists between the clinical signs and the different degrees of severity of spavin. Finally, the frequency and severity of spavin in dairy cows in loose housing was compared with the frequency and severity of this condition in tied dairy cows.

\section{MATERIAL AND METHODS}

Tied cows (herd A)

This herd is being used for a study of durability (Berglund et al. 1980). The cows belong to 3 breeds, Swedish Red and White (SRB), Swedish Friesian (SLB), Swedish Jersey (SJB), and a cross breed $(\mathrm{SRB} \times \mathrm{SLB})$. Calves of own or outside known stock were recruited before 2 months of age. When they were 14-17 weeks old they were divided in 2 feed intensity groups, $\mathrm{H}=$ high intensity, and $\mathrm{N}=$ normal intensity. The animals on the high energy feeding calved earlier. For the heavier breeds, SRB, SLB and SRB $\times$ SLB, the lactation period began at a weight of $500 \pm 30 \mathrm{~kg}$, which was reached at about 25 months of age ( $759 \pm 34$ days) for the $\mathrm{H}$ group, and at 28 months of age ( $848 \pm$ 
24 days) for the $\mathrm{N}$ group. The SJB breed had the first lactation period at $360 \pm 20 \mathrm{~kg}$, which was reached at about 23 months of age (691 \pm 19 days) for the $H$ group and 27 months of age (798 \pm 41 days) for the $N$ group. The average daily gain from 60 to 660 days for the heavy breeds, SRB, SLB and SRB $\times$ SLB, was $614 \pm 9$ $\mathrm{g}$ for group $\mathrm{H}$, and $468 \pm 9 \mathrm{~g}$ for group $\mathrm{N}$. The average daily gain during the same period was for the SJB cows about $510 \mathrm{~g}$ for group $\mathrm{H}$, and about $430 \mathrm{~g}$ for group $\mathrm{N}$.

Feed during the young stock period consisted of hay and grass silage and a concentrate which contained grain and oil cakes + minerals. The relationship between feed concentrate and fodder was, from 27 weeks of age, 3:7 calculated on the basis of energy content. Mineral supplementation followed the Swedish standard (Eriksson et al. 1976). After calving, the cows were fed with hay and grass silage as fodder in equal amounts, calculated on the basis of dry matter. Based on milk production, the cows were also fed a contrate feed mixture (grain, oil cakes, minerals and sugar beet). Mineral supplementation followed the Swedish standard.

The average yearly milk production in the herd, expressed as $\mathrm{kg} 4 \%$-milk was for 3 successive years $5,314 \mathrm{~kg}$ for SRB, 5,564 $\mathrm{kg}$ for SLB, $5,455 \mathrm{~kg}$ for SRB $\times$ SLB, and $4,739 \mathrm{~kg}$ for SJB. All breeds produced about $10 \mathrm{~kg}$ milk/ $\mathrm{kg}$ body weight/year, except for the SLB cows, which produced about $11 \mathrm{~kg} 4 \%$-milk $/ \mathrm{kg}$ body weight/year.

From the age of 3 months, the animals were tied up on a standing of ground concrete. The standing measured $1.20 \mathrm{~m}$ in width and $2.10-2.28 \mathrm{~m}$ in length, with an iron grid covered dung channel directly behind the standing. Saw dust was used as bedding material.

During the young stock period, some of the animals were allowed to move freely in outdoor pens. These pens were $28 \times 53$ $m$ and had a sand floor. The exercise period began when the animals were 6 months old and continued to the first lactation. It consisted of two 5 -h perioas from 9 a.m. to 2 p.m. each week from April to October. During the rest of the year, the animals were outside less often due to poor weather conditions in the winter period.

Based on the amount of exercise given, the animals of the herd could be divided into 2 well defined groups. One group was allowed to exercise as mentioned above from 6 months of age, 
Table 1. Tied animals (Herd A). Number of cows of different breed, amount of exercise and feed intensity during young stock period.

\begin{tabular}{|c|c|c|c|c|c|c|c|c|c|c|c|}
\hline \multirow{3}{*}{$\begin{array}{l}\text { Amount of exercise } \\
\text { prior to first lactation }\end{array}$} & \multicolumn{10}{|c|}{ Feed intensity within breeds } & \multirow{3}{*}{$\sum_{\text {Total }}$} \\
\hline & \multicolumn{2}{|c|}{ SRB } & \multicolumn{2}{|c|}{$\mathbf{S R B} \times \mathbf{S L B}$} & \multicolumn{2}{|c|}{ SLB } & \multicolumn{2}{|c|}{ SJB } & \multicolumn{2}{|c|}{ All breeds } & \\
\hline & $\mathbf{H}$ & $\mathbf{N}$ & $\mathbf{H}$ & $\mathbf{N}$ & $\mathrm{H}$ & $\mathbf{N}$ & H & $\mathbf{N}$ & H & $\mathbf{N}$ & \\
\hline None & 15 & 14 & 4 & 7 & 9 & 10 & 6 & 6 & 34 & 37 & 71 \\
\hline Irregular & 11 & 11 & 10 & 4 & 2 & 3 & 5 & 4 & 28 & 22 & 50 \\
\hline Regular & 11 & 9 & 0 & 3 & 11 & 9 & 3 & 2 & 25 & 23 & 48 \\
\hline $\begin{array}{l}\Sigma \text { feed intensity } \times \\
\text { breed }\end{array}$ & 37 & 34 & 14 & 14 & 22 & 22 & 14 & 12 & 87 & 82 & 169 \\
\hline$\Sigma$ breed & & 71 & 2 & 8 & 4 & 4 & 2 & 6 & - & - & \\
\hline
\end{tabular}

$\mathrm{H}=$ high, $\mathrm{N}=$ normal feed intensity.

another group was not given any exercise before the first lactation period. A third group was given some exercise, but without any regularity (Table 1 ). During the time of the investigation (November 1974-May 1980) there were 169 animals that lived to be at least 18 months of age. These animals were included in the present investigation. The management of the herd followed the standards used in the Swedish dairy industry. That means that animals were culled continuously for reasons of infertility, low milk production, etc. The majority of the cows studied were at the end of the investigation (1980) in their first, second or third lactation, which means that the cows were about $24-48$ months old.

\section{Cows in loose housing (herd B)}

These cows were kept in a so-called warm loose housing system with manure disposal by scrapers. In addition, they were allowed to graze during the summer months (May through September). All the animals were of the own stock of the herd, and they belonged to the SRB, SLB and SRB $\times$ SLB breeds.

After rearing of the calves in single boxes, some of the calves were kept for a period of time ( $2-6$ months of age) in a communal box having a slotted concrete floor, whereas others were kept in a pen having a scraper manure system. From $6-7$ months of age, the animals were maintained in "cold loose housing" until the first lactation period. 
The young stock was allowed free access to hay and straw, and small amounts of silage were given from about 7 months of age. About $1 \mathrm{~kg}$ of a concentrate feed mixture, comprised of grain, oil cakes and minerals, was given to each animal. In addition, the animals had free access to minerals and a salt lick placed in a separate manger. From about 6 months of age, the animals were allowed to graze during the summer. The average daily gain for the young stock in the herd was about $550 \mathrm{~g} / \mathrm{day}$, and the first lactation period started on the average at 28-30 months of age.

The lactating cows in the herd were each fed $7 \mathrm{~kg}$ dry matter grass silage and $2 \mathrm{~kg}$ hay. They had free access to straw and a concentrate feed mixture (as above) was given in proportion to the milk production. The cows also had free access to minerals in a separate manger. The average milk production of the herd was during 3 successive years about $5,800 \mathrm{~kg} 4 \%$-milk/year.

In herd B, the SRB breed dominated. A total of 33 cows of the $\mathrm{SRB}$ breed from this herd were radiographed on 2 occasions in May/June 1980. In order to compare the radiographic examination of the cows maintained in loose housing with the cows that were tied up, a reference group containing 33 animals of the SRB breed of about the same age was randomly selected from herd A's tied dairy cows. The mean age was $56 \pm 21$ months for the cows in loose housing, and $51 \pm 10$ months for the tied cows.

\section{Radiographical examination}

The animals of herd $A$ were first radiographed at 3 months of age and then at 6,9 , and 12 months. From then on, radiographic examinations were made with 6 months interval. A standard Xray unit was used for all examinations. Exposure data were $\mathrm{kV}$ $60-100$, mA 25-40, exposure time $0.04 \mathrm{~s}$, and film focus distance (ffd) $80 \mathrm{~cm}$. The animals of herd $B$ were radiographed using a standard mobile X-ray unit. Exposure data were kV 70_95, mA 4 , exposure time $0.25 \mathrm{~s}$ and ffd $80 \mathrm{~cm}$. The films were developed in an Agfa-Gevaert 60 processor.

One radiograph was taken in a lateral medial projection of the left hock joint including the distal portion of the tibia and the proximal part of the metatarsus (Fig. 1). If the animal had spavin, a radiograph was also taken in lateral projection of the right hind leg in order to determine if the lesion was bilateral. 
Clinical examination - evaluation of leg position and movements

All the animals of herd A except those in calf boxes were clinically examined every month. The extremities of the animals were inspected and palpated. Hock joint effusions and swellings around the hocks, so-called tarsal cellulitis, were noted and graded as being slight, moderate or severe.

In a yearly repeated examination special attention was paid to the distance between the hock joints. The first of these inspections was made during the first gestation period. During the middle of the first, second and third lactations further inspections were then made.

The space between the hocks was determined using a 3-point scale where $1=$ normal space between the hocks, $2=$ moderate decrease of space between the hocks, and $3=$ very little space between the hocks (valgus deformity).

The angle between the tibia and the metatarsus was also measured. This was done using a specially designed measurer and the measurement was made when the animal put weight on both hind legs.

The movement of the hind legs was examined and noted once a year in connection with the trimming of the hoofs. The pattern of motion of the hind legs was noted using a 3-point scale. The following criteria were used to group the animals according to this scale:

$\mathrm{I}=$ Moves freely, normal gait and good flexion of the hocks.

II = No reluctance to move, normal motion pattern of the hind legs, but somewhat limited flexion of hocks.

$\mathrm{III}=\mathrm{A}$ certain reluctance to move. Restricted movements of the hind legs. The legs were kept straight leading to a short step with the toes barely lifted from the ground when walking.

\section{Morphological examination}

The hock joints of 17 cows of herd A which were slaughtered during 1980 were examined. Ten hocks from these cows were clinically and radiographically normal. Seven of the animals had spavin which could be diagnosed radiographically.

The specimens were first radiographed and the first intertarsal joint were opened from the medial side and inspected and the talus and calcaneus were removed. Remainder of the hocks 
and the proximal metatarsal bone were then sawn sagittally in the median plane. The medial part of the specimen was then sawn in $5 \mathrm{~mm}$ thick sagittal slabs, which were radiographed on Kodalith Ortho type 3 envelope wrapped films. A custom built roentgen apparatus with a Machlett AEG 50 A roentgen tube with a $1.5 \times 1.5 \mathrm{~mm}$ tungsten target and a $1 \mathrm{~mm}$ thick beryllium window was used. Exposure data were $\mathrm{kV} \mathrm{27,} \mathrm{mA} \mathrm{22}$, exposure time $20 \mathrm{~min}$ and ffd $40 \mathrm{~cm}$.

Specimens from the medial part of the fused central and 4 th tarsal bones $\left(\mathbf{T}_{\mathrm{c}+4}\right)$, the fused $2 \mathrm{nd}$ and 3rd tarsal bones $\left(\mathrm{T}_{2+3}\right)$ and the proximal part of the fused 3rd and 4th metatarsal bones $\left(\mathrm{Mt}_{3+4}\right)$ (Fig. 1) together with the connecting joint surfaces were fixed in $10 \%$ neutral formalin. Specimens were taken for histologic (A) and microradiographic (B) examination.

A. The specimens were decalcified under vacuum in $10 \%$ formic acid buffered to $\mathrm{pH} 4.5$ with sodium citrate. After embedding in paraffin, $6 \mu \mathrm{m}$ thick sections were made which were stained with hematoxylin and eosin. The degree of changes in the joint cartilage was evaluated histologically using the following criteria:

$0=$ Normal joint cartilage.

$\mathbf{1}=$ Intact cartilage, but reduced stainability, increased cellularity of the surface layer and increased cluster formation.

$2=$ Erosion or necrosis of the surface of the joint cartilage with decreased cartilage thickness.

$3=$ Disappearance of the cartilage with partial or complete fusion of the bones.

B. The specimens were fixed in absolute alcohol and embedded in methylmethacrylate without previous decalcification. They were sawn in $200 \mu \mathrm{m}$ thick sections which were ground down to a thickness of about $100 \mu \mathrm{m}$. The sections were then taped to Kodak High Resolution glass plates and radiographed using the previously described custom built $\mathrm{X}$-ray apparatus. Exposure data were $\mathrm{kV} \mathrm{25}, \mathrm{mA} \mathrm{20}$, exposure time $15 \mathrm{~min}$ and ffd $40 \mathrm{~cm}$. The glass plates were hand developed under constant agitation and then examined under the microscope. 


\section{Genetics}

The possible role of genetic factors for the development of spavin was siudied. The statistical analysis was done using $\chi^{2}$ test with the application of Yate's correction factor when necessary and using the Student's t-test when appropriate (Crow et al. 1960).

\section{Radiographic findings}

\section{RESULTS}

Osteophytes were observed primarily on the dorso-medial aspect of the small bones of the hock. They most often occurred marginal to the joint space between $\mathrm{T}_{\mathrm{c}+4}$ and $\mathrm{T}_{2+3}$. Less common and having a later appearance were marginal osteophytes around the joint space between $\mathrm{T}_{2+3}$ and $\mathrm{Mt}_{3+4}$. Osteophyte formation led to an indistinct joint space in the lateral projection.

In more advanced cases of spavin with increased osteophyte development, marked deformation of $\mathbf{T}_{2+3}$ and also $T_{c+4}$ was seen in both the lateral and the AP-projections. The normal rectangular form of the bone was changed being more narrow and drawn out to a boat form. The space between the bones was smaller and more difficult to discern due to the presence of the marginal osteophytes. After a certain length of time, fusion of $\mathrm{T}_{\mathrm{c}+4}$ and $\mathrm{T}_{2+3}$ was observed on the radiographs.

The radiographic changes as well as the development of the severeness of the changes with increasing age of the cows are presented in Figs. 2-4.

Radiological signs of spavin of the type described above in the cows of herd A became noticeable between 18 and 24 months of age. The mean age of the animals was $20.4 \pm 5.2$ months. In most animals, the changes became steadily worse. The rate of development varied between animals, but generally fusion was the end result (Fig. 4). Of the animals that had radiographically diagnosed spavin and were 4 years old or more (24 cows), $71 \%$ (17 cows) had some degree of bony fusion. The first signs of fusion were apparent in the affected animals at 4 years of age. The changes were nearly always bilateral, only 1 out of 27 cows with spavin had unilateral changes. The SLB cows had a lower mean incidence $(20 \%)$ of spavin than cows of the SRB (42\%) and the SJB (50\%) (Table 2). Among the SJB cows the incidence of spavin was higher (71 \%) in cows reared on a high feeding intensity in comparison with the incidence $(25 \%)$ in those reared 
THE INFLUENCE OF AGE, BREED, REARING INTENSITY AND EXERCISE ON THE INCIDENCE OF SPAVIN

IN SWEDISH DAIRY CATTLE

A CLINICAL AND MORPHOLOGICAL INVESTIGATION

By

Torbjörn Holmberg and Sven Reiland 


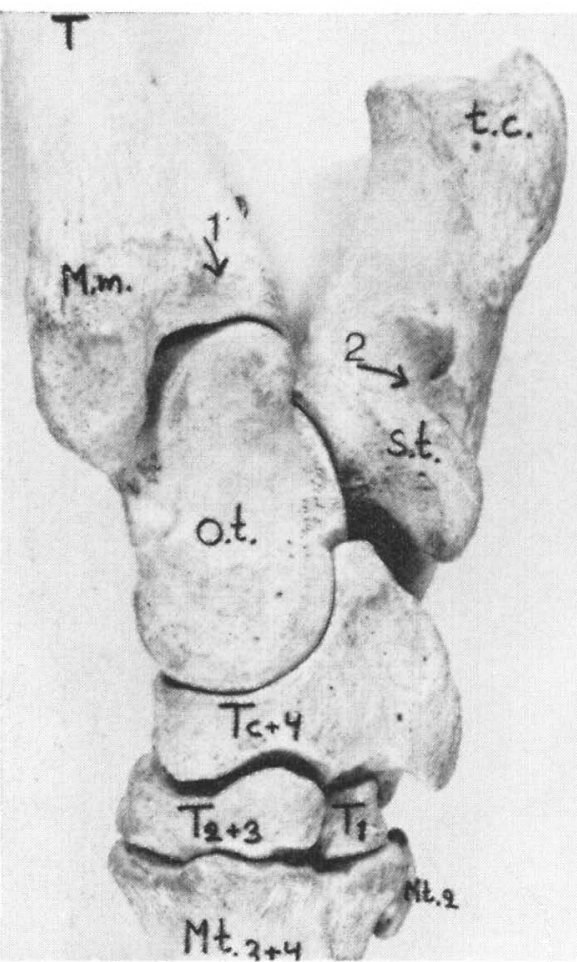

a

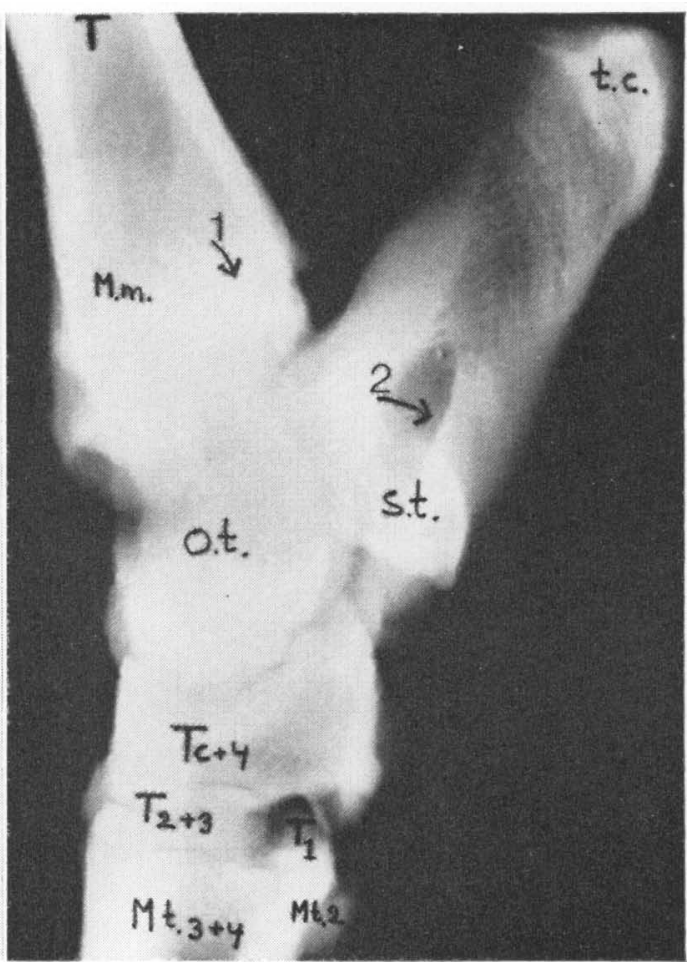

b

F i g u r e 1. Right hock joint region of dairy cow.

a. Medial aspect of mascerated specimen.

b. Radiograph.

1 = groove for tendon of long digital flexor. $2=$ groove for deep flexor tendon. $\mathrm{T}=$ tibia. $\mathrm{Mm}=$ medial malleolus. $\mathrm{tc}=$ tuber calcis. ot $=$ tibial tarsal bone (talus). $\mathbf{s t}=$ fibular tarsal bone (sustentaculum). $T_{c+4}=$ fused central and fourth tarsal bones. $\mathrm{T}_{2+3}=$ fused second and third tarsal bones. $\mathrm{T}_{1}=$ first tarsal bone. $\mathrm{Mt}_{3+4}=$ large metatarsal or fused third and fourth metatarsal bones.

$\mathrm{Mt}_{2}=$ small or second metatarsal bone. 


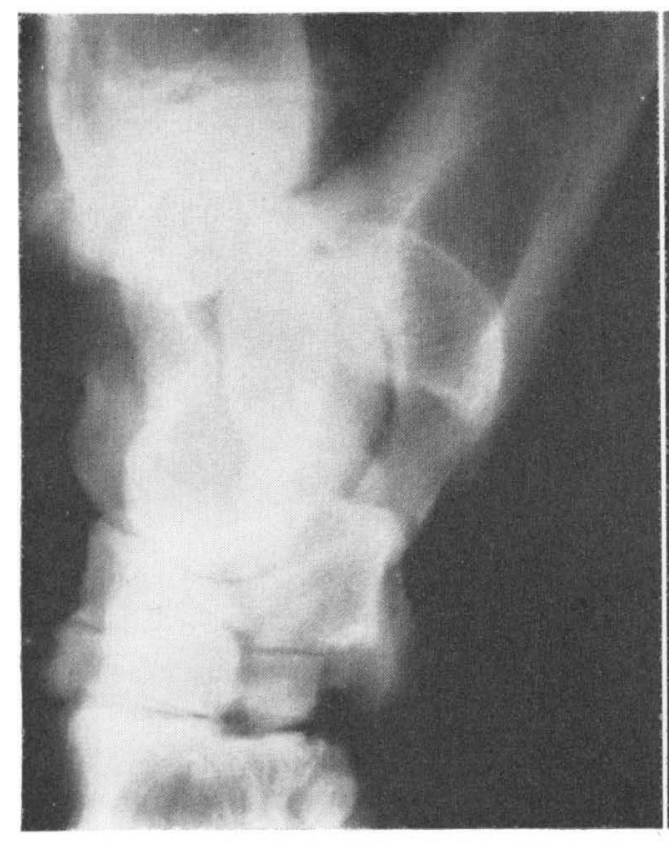

a

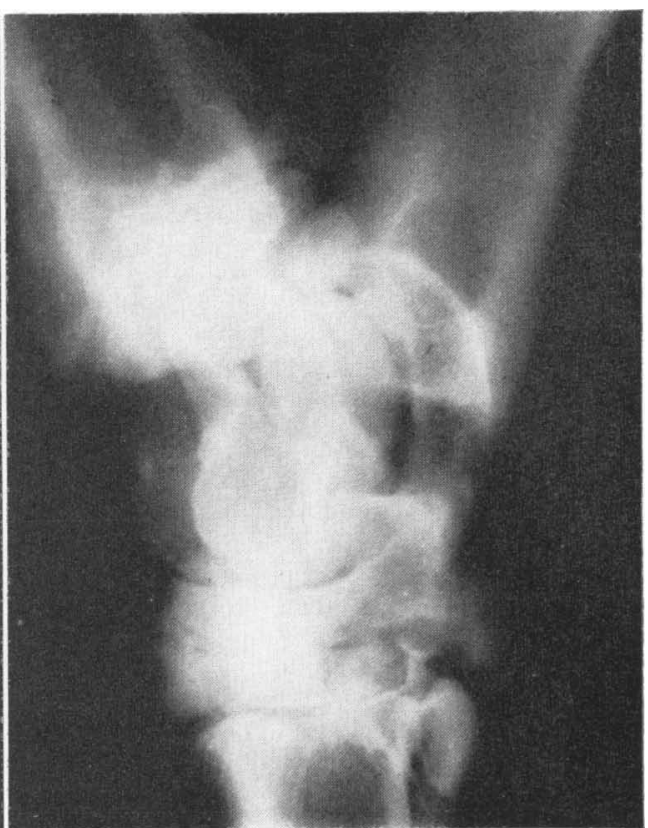

b

F i g u r e 2. Lateral radiographs of the left hock joint region of two SRB cows $31 \frac{1}{2}$ years old.

a. No pathological changes.

b. Marked osieophyte formation, indistinct joint spaces and deformation of the tarsal bones as signs of advanced spavin. 


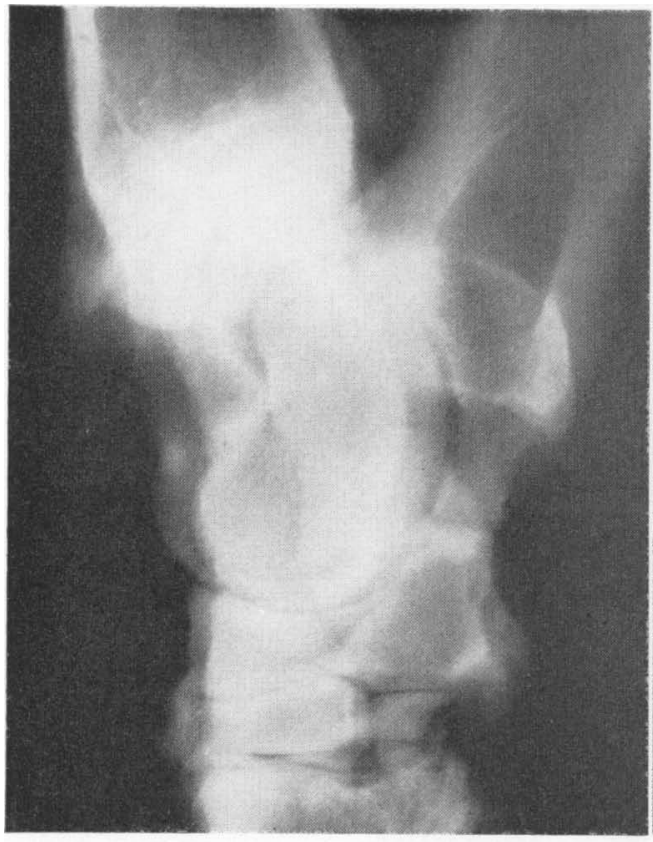

a

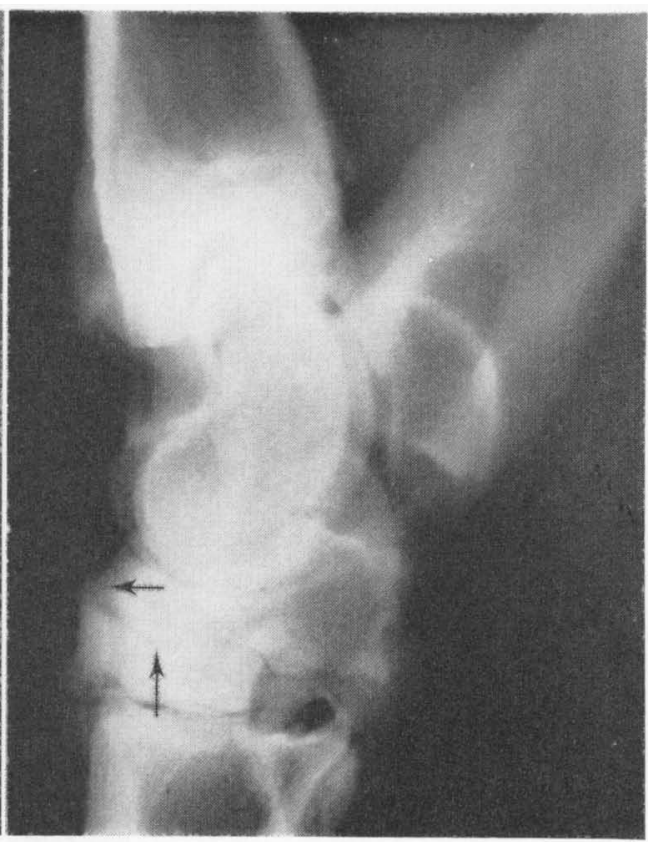

b

F igu re 3. Lateral radiographs of the left hock joint region of the two SRB cows in Fig. 2, now 5 years old.

a. No pathological changes.

b. Massive osteophyte formation on the cranio medial aspect (arrow) with signs of fusion between $T_{c+4}$ and $T_{2+3}$ (arrow). Deformation of $T_{2+3}$.

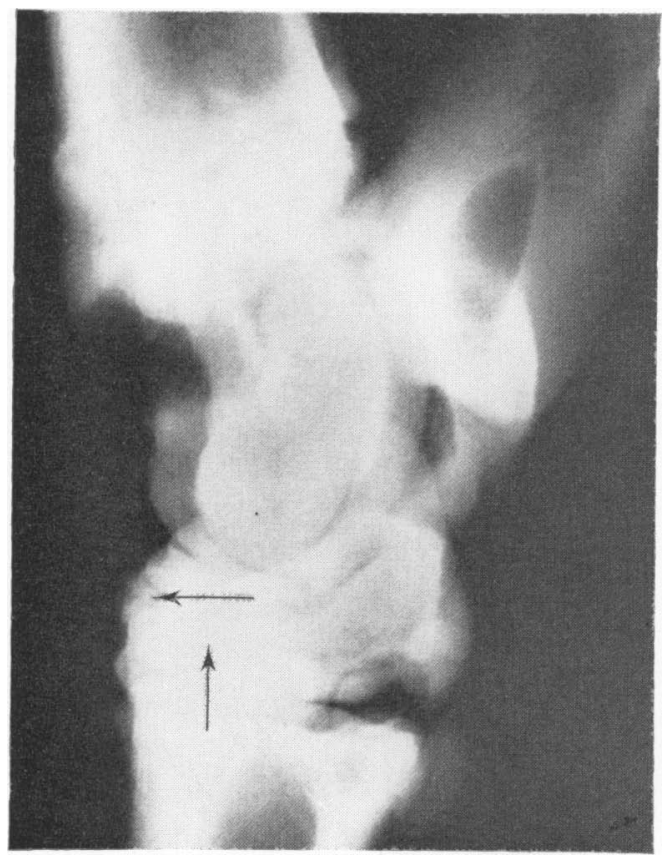

F i g u r e 4. Lateral radiograph of the left hock joint region of a $5^{1 / 2}$ years old SJB cow with severe osteoarthrosis of the arthrodial joints. Very large marginal osteophytes (arrow) and fusion between several tarsal bones (arrow). 

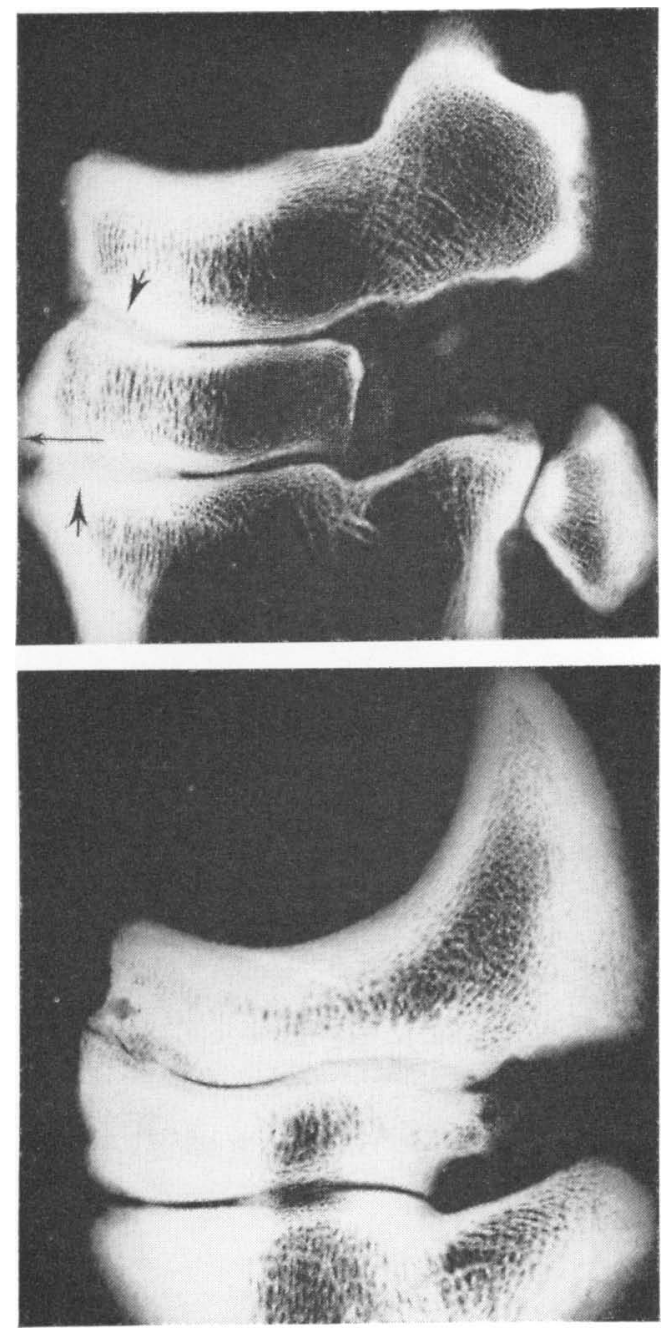

F igure 5. Radiograph of sagittal slab of the medial half of the distal right hock from a SLB cow $2 \frac{1}{2}$ years old without clinical signs of spavin. Narrowing of the joint spaces and formation of new bone between $T_{c+4}$ and $\mathrm{T}_{2+3}$ and between $\mathrm{T}_{2+3}$ and $\mathrm{Mt}_{3+4}$ (arrows). Marginal osteophyte formation (arrow).

F ig u r e 6. Radiograph of sagittal slab of the medial half of the distal right hock from a SJB cow 5 years old. The diagnosis of spavin was made in vivo. There is deformation of $\mathrm{T}_{2+3}$ and osteophyte formation and signs of fusion between $T_{c+4}$ and $T_{2+3}$. 

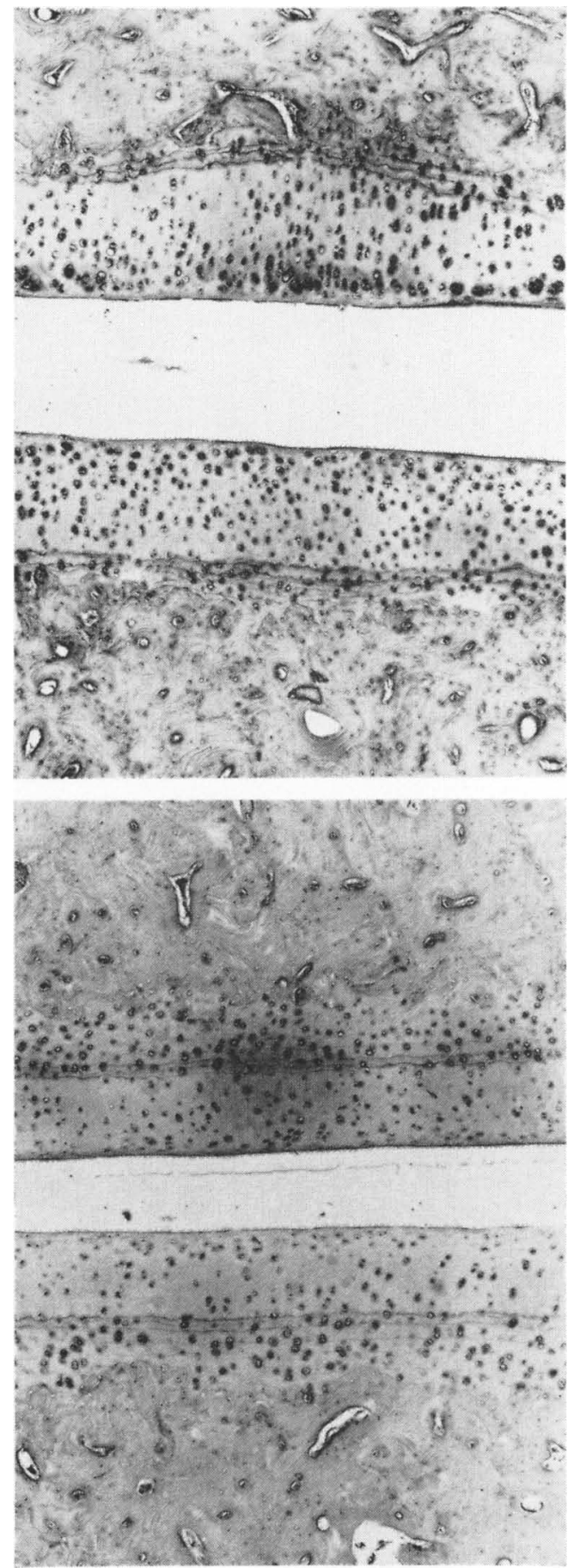

Fig u r e 7. Histologic section of the joint surfaces of $\mathrm{T}_{\mathrm{c}+4}$ and $\mathrm{T}_{2+3}$ in the tarsal joint of a 5 years old SLB cow. Normal appearance of the joint cartilage. $\mathrm{H} \& \mathrm{E} \times 60$.

F i g u r e 8. Histologic section of the joint surfaces of $T_{c+4}$ and $T_{2+3}$ of a 4 years old SRB cow without macroscopic evidence of spavin. Normal thickness of joint cartilage and intact surface. Reduced stainability of surface layer and increased cellularity with cluster formation (arthrosis degree 1). $\mathrm{H} \& \mathrm{E} \times 60$. 

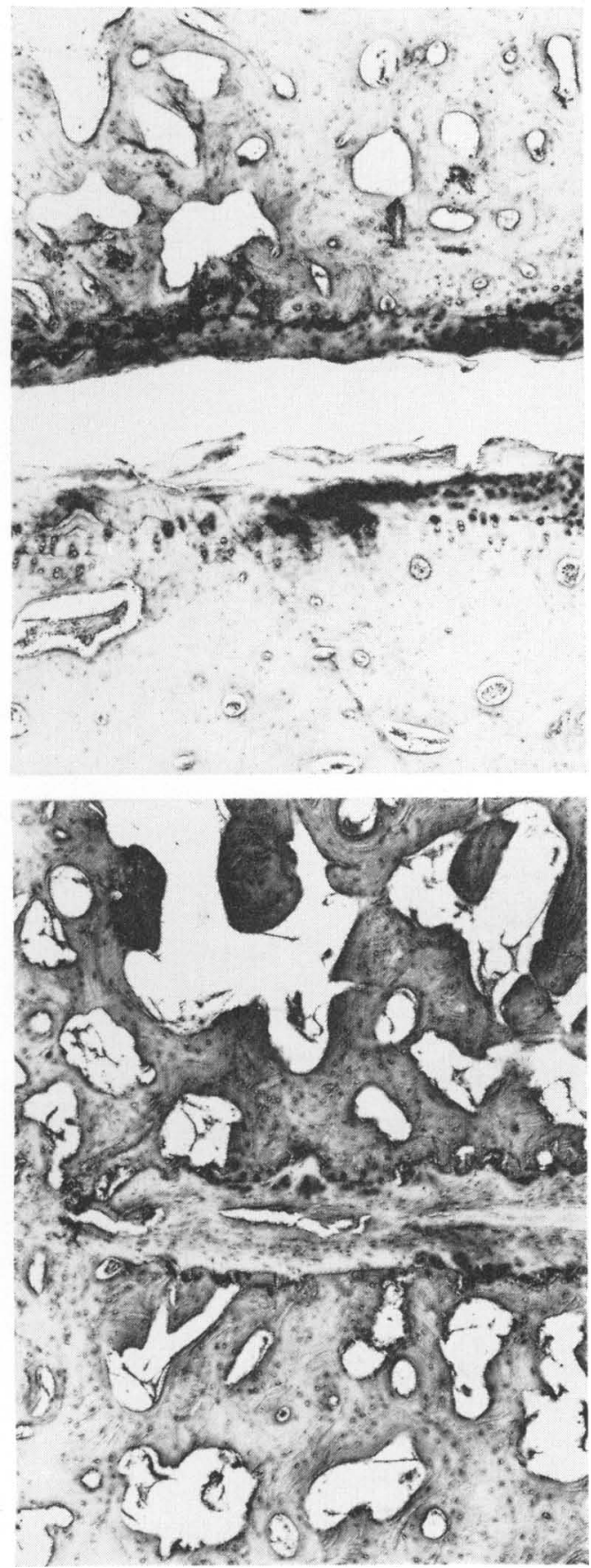

Fig u r e 9. Histologic section of the joint surfaces of $\mathrm{T}_{\mathrm{c}+4}$ and $\mathrm{T}_{2+3}$ of a 5 years old SJB cow with changes of spavin not diagnosed in vivo but found post mortem. Erosion of the surface of the joint cartilage with decreased cartilage thickness (arthrosis degree 2 ). $\mathrm{H} \& \mathrm{E} \times 60$.

F i g u r e 10 . Histologic section of the joint surfaces of $\mathrm{T}_{\mathrm{c}+4}$ and $\mathrm{T}_{2+3}$ of a 5 years old SLB cow with signs of spavin diagnosed in vivo. Partly bony fusion, disappearance of joint space and marked degeneration of cartilage (arthrosis degree 3 ). $\mathrm{H} \& \mathrm{E} \times 60$. 


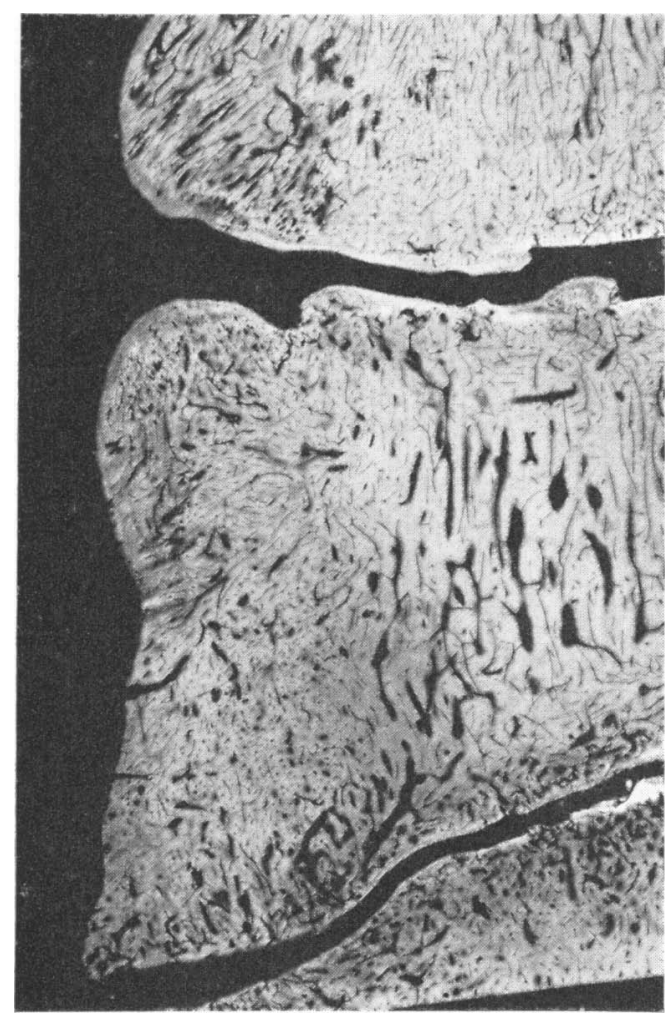

Figure 11. Microradiograph of a sagittal section of the cranial part of $\mathrm{T}_{2+3}$ with adjacent joints and bones from a 5 years old SRB cow with changes of spavin not diagnosed in vivo but found post mortem. Compact bone structure with excessive formation of new bone cranially. Irregular subchondral bone with areas of new bone formation alternating with areas of sclerosis. $\times 6$.

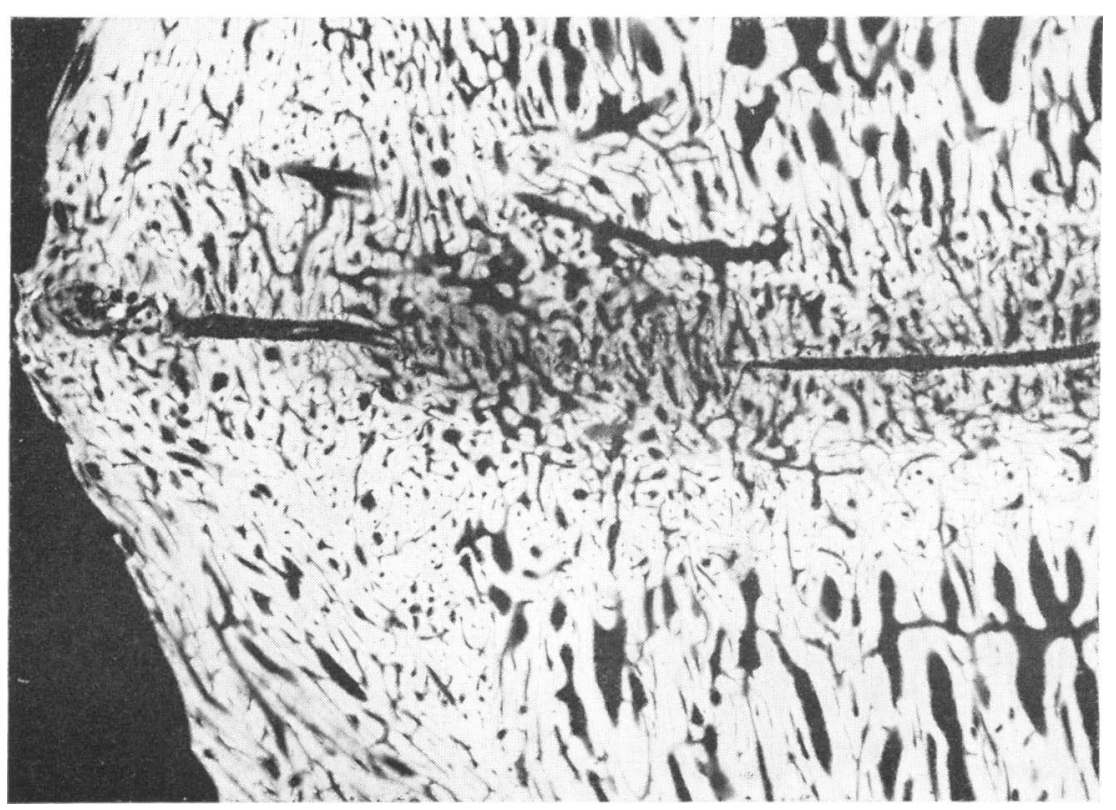

Figure 12. Microradiograph of a sagittal section of the cranial part of the joint between $\mathrm{T}_{\mathrm{c}+4}$ and $\mathrm{T}_{2+3}$ of a 5 years old SLB cow in which spavin was diagnosed in vivo. Fusion of the joint by bridges of new bone. $\times 10$. 
T a b l e 2. In vivo diagnosed spavin in 169 tied dairy cows (Herd A); distribution according to breed and feed intensity during the young stock period.

\begin{tabular}{|c|c|c|c|c|c|c|c|c|c|c|}
\hline \multirow{2}{*}{$\frac{\text { Breed }}{\text { Feed intensity }}$} & \multicolumn{2}{|c|}{$\begin{array}{c}\text { SRB } \\
\mathrm{n}=71\end{array}$} & \multicolumn{2}{|c|}{$\begin{array}{c}\mathrm{SRB} \times \mathrm{SLB} \\
\mathrm{n}=\mathbf{2 8}\end{array}$} & \multicolumn{2}{|c|}{$\begin{array}{l}\text { SLB } \\
\mathrm{n}=44\end{array}$} & \multicolumn{2}{|c|}{$\begin{array}{c}\text { SJB } \\
\mathrm{n}=26\end{array}$} & \multicolumn{2}{|c|}{$\begin{array}{c}\text { All breeds } \\
\mathbf{n}=\mathbf{1 6 9}\end{array}$} \\
\hline & $\begin{array}{c}\mathbf{H} \\
\mathbf{n}=\mathbf{3 7}\end{array}$ & $\begin{array}{c}\mathrm{N} \\
\mathrm{n}=\mathbf{3 4}\end{array}$ & $\begin{array}{c}\mathrm{H} \\
\mathrm{n}=14\end{array}$ & $\begin{array}{c}\mathrm{N} \\
\mathrm{n}=14\end{array}$ & $\begin{array}{c}\mathrm{H} \\
\mathbf{n}=\mathbf{2 2}\end{array}$ & $\begin{array}{c}N \\
n=22\end{array}$ & $\begin{array}{c}\mathrm{H} \\
\mathrm{n}=\mathbf{1 4}\end{array}$ & $\stackrel{N}{n=12}$ & $\stackrel{H}{n=87}$ & $\stackrel{N}{n=82}$ \\
\hline $\begin{array}{l}\text { Frequency of } \\
\text { spavin }(\%)\end{array}$ & 43 & 41 & 29 & 43 & 18 & 22 & 71 & 25 & 39 & 34 \\
\hline Mean \% & \multicolumn{2}{|c|}{42} & \multicolumn{2}{|c|}{36} & \multicolumn{2}{|c|}{20} & \multicolumn{2}{|c|}{50} & \multicolumn{2}{|c|}{37} \\
\hline
\end{tabular}

$\mathrm{n}=$ number of cows; $\mathrm{H}=$ high; $\mathrm{N}=$ normal feed intensity

significant levels for young stock feed intensity

$\chi^{2}$ for SJB: $3.870, P<0.05$; others not significant

significance levels for breed

$\chi^{2}$ for SLB/SRB: 4.830, $\mathrm{P}<0.05$

for SLB/SJB: $5.320, \mathrm{P}<0.05$; others not significant

on a normal fecding intensity. There was no difference in the frequency of spavin found in animals that were exercised during the young stock period and those that were not exercised. However, in SRB cows kept in the loose housing herd B, a lower incidence of spavin $(21 \%)$ was found than in the tied SRB cows (52\%) in herd A.

\section{Clinical findings}

Of the 169 examined animals of herd A, 52 showed clinical signs like effusion of the hock joints and swelling around the hocks. The frequency of spavin was not higher in the animals showing severe clinical signs than in the animals that only showed slight clinical changes.

The motion studies revealed no general difference in the pattern of hind leg movements between cows with and without spavin. Cows with anchylosis of the hocks were, however, somewhat restricted in the hind leg movements. Straight hocks and poor lifting of the toes were seen.

With increasing ages of the animals, a shifting of the position of the hind legs towards a shorter distance between the hocks (valgus deformity) was observed (Table 3 ). There was, however, no difference in the distance between the hocks in animals with and without spavin until in the third lactation period, when those 
T a b l e 3. Distance between the hocks (valgus deformity) of tied dairy cows; age distributed. A scale is used where $1=$ normal hind legs and $3=$ marked valgus deformity (see methods).

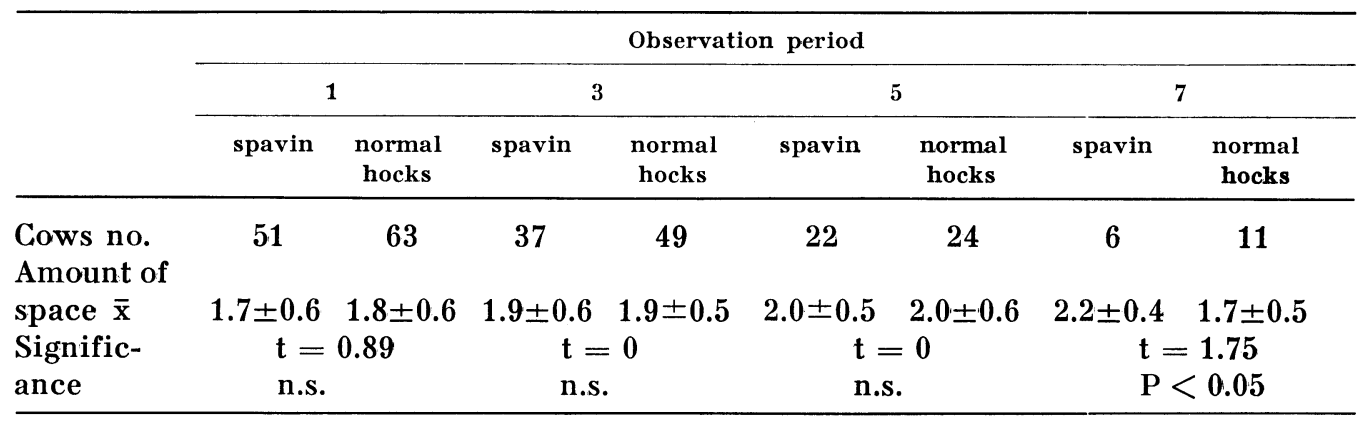

$1=$ Observation period during the first gestation

$3=$ Observation period during the middle of the first lactation

$5=$ Observation period during the middle of the second lactation

$7=$ Observation period during the middle of the third lactation

n.s. $=$ not significant

with spavin had a shorter distance between the hocks. No difference with regards to the angle of the hock was found between cows with and without spavin.

\section{Morphological findings}

Spavin was diagnosed in 13 of the 17 cows examined morphologically. In 7 of these cows spavin had been diagnosed radiographically in vivo (Table 4). On radiographs of slabs changes most often occurred between $T_{c+4}$ and $T_{2+3}$, but also between $\mathrm{T}_{2+3}$ and $\mathrm{Mt}_{3+4}$ (Fig. 5). Obvious deformation of bones especially $\mathrm{T}_{2+3}$ and of the joint surfaces could be observed on the radiographs (Fig. 6).

In 4 cows without macroscopic evidence of spavin slight changes could be seen histologically in the cartilage of the arthrodial joints (Fig. 8).

In 6 cows with macroscopic evidence of spavin, but where lesions were not found radiographically in vivo, more advanced changes were seen histologically in the joint cartilage (Fig. 9).

Seven cows with spavin noted already in vivo had the most severe histologic changes in the joint cartilage (arthrosis, degree 3) (Fig. 10). The average value calculated on histological degree of arthrosis in 7 cows with spavin diagnosed in vivo was 2.3 and in 10 cows without radiographic changes in vivo 1.5 . 
T a b l e 4. Degree of degenerative tarsal joint changes in 17 randomly selected tied dairy cows with and without in vivo diagnosed spavin.

\begin{tabular}{|c|c|c|c|c|c|c|c|c|}
\hline \multirow[t]{2}{*}{ Breed } & \multirow[t]{2}{*}{$\begin{array}{c}\text { Age } \\
\text { (years) }\end{array}$} & \multirow[t]{2}{*}{$\begin{array}{l}\text { Young stock } \\
\text { feed intensity }\end{array}$} & \multicolumn{2}{|c|}{$\begin{array}{l}\text { Spavin } \\
\text { in vivo }\end{array}$} & \multicolumn{2}{|c|}{$\begin{array}{l}\text { Spavin } \\
\text { macroscopic- } \\
\text { ally post } \\
\text { mortem }\end{array}$} & \multicolumn{2}{|c|}{$\begin{array}{l}\text { Histological } \\
\text { degree of } \\
\text { arthrosis }\end{array}$} \\
\hline & & & $d x$ & $\sin$ & $d x$ & $\sin$ & $d x$ & $\sin$ \\
\hline SLB & 5.13 & $\mathbf{H}$ & 0 & 0 & 0 & 0 & 0 & 2 \\
\hline SLB & 4.23 & $\mathrm{H}$ & 0 & 0 & 0 & 0 & 1 & 0 \\
\hline SJB & 3.43 & $\mathrm{H}$ & 0 & 0 & 0 & 0 & 1 & 0 \\
\hline SJB & 5.97 & $\mathrm{H}$ & 0 & 0 & 0 & 0 & 1 & 1 \\
\hline SLB & 2.39 & $\mathbf{N}$ & 0 & 0 & + & + & 2 & 2 \\
\hline SRB & 4.89 & $\mathbf{H}$ & 0 & 0 & + & + & 2 & 1 \\
\hline SRB & 3.89 & $\mathbf{H}$ & 0 & 0 & + & + & 2 & 3 \\
\hline SRB & 3.93 & $\mathrm{H}$ & 0 & 0 & + & + & 2 & 2 \\
\hline SRB & 5.33 & $\mathbf{H}$ & 0 & 0 & + & + & 2 & 2 \\
\hline $\mathrm{SLB} \times \mathrm{SRB}$ & 5.19 & $\mathbf{H}$ & 0 & 0 & + & + & 2 & 2 \\
\hline SLB & 4.85 & $\mathbf{N}$ & + & + & + & + & 3 & - \\
\hline SRB & 2.74 & $\mathbf{H}$ & + & + & + & + & 2 & - \\
\hline SRB & 4.05 & $\mathbf{N}$ & 0 & + & 0 & + & 1 & 3 \\
\hline SRB & 4.14 & $\mathbf{N}$ & + & + & + & + & 3 & 2 \\
\hline $\mathrm{SLB} \times \mathrm{SRB}$ & 4.51 & $\mathrm{H}$ & + & + & + & + & 3 & 3 \\
\hline SJB & 5.05 & $\mathbf{H}$ & + & + & + & + & 3 & 3 \\
\hline SJB & 3.64 & $\mathbf{H}$ & + & + & + & + & 2 & 2 \\
\hline
\end{tabular}

$\mathrm{H}=$ high, $\mathrm{N}=$ normal young stock feed intensity

$+=$ spavin diagnosed, $0=$ spavin not diagnosed

- = not examined

$\mathrm{dx}=$ right hock, $\sin =$ left hock

On microradiographs were found sclerosis of the tarsal bones with excessive formation of new (woven) bone marginally (Fig. 11). The osteophytes were most prominent in cows with spavin diagnosed in vivo. In cows with fusion of the arthrodial joints (arthrosis, degree 3 ) there were bridges of woven bone connecting the tarsal bones (Fig. 12).

\section{Genetics}

An inherited predisposition for spavin was found in the cows of herd A (Table 5). A total of 32 of the cows had offspring which met the requirement for being included in this part of the investigation. Of these 32 animals, 11 had radiographically diagnosed spavin, whereas 21 were negative on radiographs. The frequency of spavin in their offspring was $64 \%$ and $19 \%$, 
T a b l e 5. In vivo diagnosed spavin in offspring of tied dairy cows, with and without spavin.

\begin{tabular}{|c|c|c|c|c|c|c|c|c|}
\hline & \multicolumn{4}{|c|}{ Spavin } & \multicolumn{4}{|c|}{ Normal tarsal joints } \\
\hline & \multirow[t]{2}{*}{ All cows } & \multicolumn{3}{|c|}{ Breed } & \multirow[t]{2}{*}{ All cows } & \multicolumn{3}{|c|}{ Breed } \\
\hline & & SRB & SLB & SJB & & SRB & SLB & SJB \\
\hline No. offspring & 11 & 6 & 2 & 3 & 21 & 8 & 10 & 3 \\
\hline $\begin{array}{l}\text { Spavin among } \\
\text { offspring }\end{array}$ & 7 & 3 & 2 & 2 & 4 & 1 & 1 & 2 \\
\hline $\begin{array}{l}\text { Spavin in } \\
\text { offspring }(\%)\end{array}$ & $64^{1}$ & & & & $19^{1}$ & & & \\
\hline
\end{tabular}

${ }^{1}$ Significance: $\chi^{2}=4.54, \mathrm{P}<0.05$

respectively. The mean age for the 2 offspring groups was about 3 years. When the offspring of animals with spavin were compared with the offspring of those without spavin with respect to the angle of the hocks and the distance between the hocks, no difference was observed. However, the number of animals studied was small. In animals of herd B, 5 of the 7 SRB cows, which had spavin, were closely related.

\section{DISCUSSION}

The present study of the Swedish dairy herd with tied cows revealed a very high incidence of spavin (37\%). Such a high incidence has not previously been reported, although it has been known since ancient times that spavin is common in cattle (Wäsle 1976, Feddersen \& Heinrich 1977). Blumenfeld (1909), Hansen (1964), van Pelt (1975) found spavin in old animals, primarily in bulls. Osteophytes and fusion of the arthrodial joints of the hock were observed in old bulls and cows of Swedish dairy breeds as a part phenomenon in osteopetrosis and hyperostosis (Zetterholm 1972). In the present study it was found that the radiographic changes in the joints in tied dairy cows were seen before the animals were 2 years old. The severity increased with increasing age, and by the time the affected animals were 4 years old or more some degree of bone fusion had occurred.

Significant differences between breeds in the incidence of spavin were observed. The SLB cows showed a lower mean incidence $(20 \%)$ of spavin than the other breeds, especially cows of the SRB $(42 \%)$ and the SJB $(50 \%)$. In the SJB the high mean 
incidence of spavin was, however, due to the high incidence $(71 \%)$ found in the cows raised on high young stock feeding intensity leading to a forced maturation and an early start of first lactation period. This relationship between high young stock feeding intensity and the incidence of spavin seen in SJB cows did not exist in the heavier breeds.

The radiographic findings and the increase in severity of the changes of the hock joints with age found in this investigation is in accordance with observations of previous studies of spavin in cattle (Groulade et al. 1960, Hansen 1964, Greenough et al. 1972). However, a difference in the incidence of spavin between breeds of cattle has not been previously reported. The high incidence of spavin in the SJB cows is in accordance with the observation of Russell \& Shaw (1978), that smaller cows have a higher incidence of injuries to the legs.

With post mortem examination of hocks from 17 tied cows, the number of cases with spavin in that group nearly doubled. Minor changes in the bones and joint cartilages of the arthrodial joints of the hock were found also in animals without spavin. These changes were considered to be an early stage in the development of arthrosis. This indicates that the diagnosis of spavin can be made clinically only in the more advanced cases, and that the initial stages of spavin are very common in tied dairy cows.

In old dairy cows and in large heavy bulls which are tied for a long period of time, degenerative joint changes are common (Shupe 1959, Schöll 1967, van Pelt 1975). Exercise has been thought to have a positive effect on degenative changes in the joint (van Pelt 1966, 1970, 1975). However, in the present study there was no significant difference in the frequency of spavin between animals which had the most exercise as young stock and those which had very little exercise. On the other hand, the dairy cows in the one herd with loose housing had a lower incidence of spavin compared to the ones from the other herd that were tied, if animals of the same age and breed group are compared.

The animals with advanced spavin and anchylosis had stiff hind leg movements, probably due to straight hocks, short steps and poor lifting of the toes.

The result of the present study indicates that genetics could play a role in frequency and severity of spavin in cattle. 


\section{ACKNOWLEDGEMENTS}

This investigation was supported by Jordbrukets försäkringsbolag, the John M. Olin Foundation, the Swedish Medical Research Council and the Swedish Council for Forestry and Agricultural Research.

\section{REFERENCES}

Assmus, G.: Gelenkserkrankungen an den Hintergliedmassen des Rindes. (Joint lesions of the hind legs in cattle). Prakt. Tierarzt $1975,56,18-20$.

Berglund, B., E. Brännäng, T. Henningsson, L. Janson, G. Josefsson, G. Lindkvist, B. Magnusson, J. Philipsson \& C. Swensson: Comprehensive experiments on traits affecting longevity in Swedish dairy cattle breeds. Swedish J. Agric. Res. 1980, 10, 159-166.

Blumenfeld, H.: Über den Spat des Rindes. (On spavin in cattle). Inaug. Diss. Dresden 1909.

Crow, E. L., A. D. Frances \& M. W. Maxfield: Statistics Manual (1st ed). Dover Publications Inc. New York 1960.

Eriksson, S., S. Sanne \& S. Thomke: Fodermedelstabeller och utfodringsrekommendationer. (Feed tables and feeding recommendations). LTs förlag, Borås 1976.

Feddersen, D. \& D. Heinrich: Anomalien und Pathologien an HaustierKnochen aus einer frühmittelalterichen Siedlung und deren Bewertung im Hinblick auf die Tierhaltung. (The skeleton of domestic animals in a colony from the Middle Ages. The importance of anomaly and pathology of bone as regards animals husbandry). Z. Tierzücht. ZüchtBiol. 1977/78, 94, 161-170.

Greenough, P. R., F. J. McCallum \& A. D. Weaver: Lameness in Cattle. Oliver \& Boyd, Edinburgh 1972, p. 289—293, p. 379—383.

Groulade, P., P., Sorel \& J. Groulade: Osteo-arthropathie chez le taureau. Etude clinique et biologique. (Osteoarthropathy in cattle. Clinical and biological studies). Bull. Acad. vét. 1960, 23, 253274.

Hansen, K. M.: Hasernes sundhed hos en AI-tyrs sønner. (The health of the hocks in progeny of an AI-bull). Kgl. Veterinær- og Landbohøjskole, Inst. f. sterilitetsforskning, Årsberetning 1964, 199210.

van Pelt, R. W. \& R. F. Langham: Degenerative joint disease in cattle. J. Amer. vet. med. Ass. 1966, 148, 535-542.

van Pelt, R. W. \& R. F. Langham: Degenerative joint disease of the carpus and fetlock in cattle. J. Amer. vet. med. Ass. 1970, 157, 953-961.

van Pelt, $R$. W.: Tarsal degenerative joint disease in cattle. Blood and synovial fluid changes. Amer. J. vet. Res. 1975, 36, 1009-1014.

Russell, A.M. \& S.R. Shaw: The Compton lameness survey 1977; a preliminary report. Animal Disease Report 1978, 2, no. 3, 5-8.

Schöll, G.: Osteoarthrosis deformans der Karpalgelenke bei Bullen. (Osteoarthrosis of the carpal joint in bulls). Inaug. Diss. München 1967. 
Shupe, J. L.: Degenerative arthritis in the bovine. Lab. Invest. 1959, 8, $1190-1196$.

SHS (The Association for Swedish Live Stock Breeding and Production) : Kontroll och seminverksamhet 1974-1975). (Control and artificial insemination 1974-1975). SHS-meddelande 1976, no. 78.

SHS (The Association for Swedish Live Stock Breeding and Production): Årsstatistik från SHS 1976/77. (Statistics of the year 1976/77 from SHS). SHS-meddelande, 1978, no. 87.

Weaver, A. D.: Slaughter house condemnations for hind leg disease in cattle. Vet. Rec. 1977, 100, 172-175.

Wäsle, R.: Gebissanomalien und patologisch-anatomische Veränderungen und Knochenfunden aus arkeologischen Ausgrabungen. (Anomalies of set of teeth and pathologic-anatomical changes of bones found at archeologic excavations). Inaug. Diss. München 1976.

Zetterholm, R.: Osteopetrosis and hyperostosis in cattle. Acta radiol., Suppl. 319, 1972, 107-116.

\section{SAMMANDRAG}

Inverkan av ålder, ras, uppfödningsintensitet och motion på frekvensen av spatt hos svensk mjölkboskap.

En radiologisk undersökning av haslederna utfördes på uppbundna kor av olika raser i en svensk mjölkkobesättning. Osteoarthros i hasens glidleder (spatt) sågs hos $37 \%$ av djuren. Förändringarna debuterade före 2 års ålder och förvärrades med stigande ålder. Vid makroskopisk och histologisk undersökning sågs osteoarthros även $i$ radiologiskt normala hasar. Undersökningen visar att frekvensen spatt hos uppbundna mjölkkor är högre än vad som kliniskt kan upptäckas. Endast äldre kor med ankylos $\mathrm{i}$ hasens glidleder uppvisade de stela bakbensrörelser som anses typiska för spatt.

Kor tillhörande svensk låglandboskap (SLB) hade en lägre frekvens av spatt $(20 \%)$ än andra raser. Inom svensk jerseyboskap (SJB) berodde den höga frekvensen av spatt $(50 \%)$ på att hela $71 \%$ av de SJB-kor som utfodrats med en högre intensitet under ungdjursperioden hade spatt. Bland SJB-kor med normal utfodringsintensitet var frekvensen av spatt $25 \%$. Ett sådant samband mellan hög utfodringsintensitet och frekvensen av spatt sågs ej inom andra raser.

Undersökta kor i en besättning med lösdrift hade en lägre frekvens av spatt än korna i den uppbundna besättningen. Avkommor till djur med spatt uppvisade en högre frekvens av spatt än avkommor till djur utan spatt.

(Received December 12, 1983).

Reprints may be requested from: Torbjörn Holmberg, the Department of Animal Hygiene, Swedish University of Agricultural Sciences, S-750 07 Uppsala, Sweden. 